\title{
РЕФОРМУВАННЯ ПРАВОВОЇ ДОПОМОГИ В КОНТЕКСТІ СУДОВОӤ РЕФОРМИ 2016 РОКУ ТА ВНЕСЕНИХ ЗМІН ДО ОСНОВНОГО ЗАКОНУ УКРАЇНИ
}

\author{
ЧЕРНЕГА Андрій Петрович - кандидат юридичних наук, доцент кафедри \\ публічного та приватного права Факультету права та міжнародних відносин \\ Київського університету імені Бориса Грінченка \\ Orcid.org/0000-0001-5016-6998 \\ ОБЛОВАЦЬКА Наталія Олександрівна - старший викладач кафедри \\ публічного та приватного права Факультету права та міжнародних відносин \\ Київського університету імені Бориса Грінченка \\ Orcid.org/0000-0002-7405-279x. \\ УДК 340.5 +341+341.9+342+342.7 \\ DOI 10.32782/NP.2020.4.18
}

Статья посвящена конституционньм гарантиям на правовую помощь в контексте изменений, внесеннъхх в Основной закон Украинъ, которьие состоялись в рамках проводимой судебно-правовой ребормь 2016 года. Проанализированъг положения конституционных изменений в сфере правосудия, в течение последних четьирех лет, охвативших не только вопросъ судоустройства и судопроизводства, но и ребормирования смежных правовых институтов - прокуратурьи, адвокатурьл, юридической помоши и исполнения судебньх решений, которье являются неотъемлемьми составляющими юстиции. Доказано, что соответствуюшие изменения в Основной Закон в сбере оказания правовой помощи являются поспешнъми, необоснованными и не соответствуюшими основнъмм принципам права, прежде всего верховенству права и отдельнълм статьям Конституции Украиньи (статьи 22, 59, 64), в которой сказано - каждвий имеет право на правовую помощь и свободнъій вылор защитника.

Ключевъге слова: правовая помощь, профессиональная юридическая помощь, институт адвокатурь, судебная реборма, монополия адвокатов.

\section{Постановка проблеми}

2 червня 2016 р. Верховна Рада України прийняла Закон № 1401-VIII «Про внесення змін до Конституції України (щодо правосуддя)», яким реорганізовано Вищу раду юстиції у Вищу раду правосуддя (кінцевим строком для обрання їі членів установлено 30 квітня 2019 р.). Остання наділяється значними повноваженнями, зокрема правом призначення Служби судової охорони та Державної судової адміністрації, правом притягнення суддів та прокурорів до дисциплінарної відповідальності; Президент, парламент та з’їзд суддів України позбавляються права звільнення суддів Конституційного Суду України - суддя може бути звільнений тільки за рішенням не менше 2/3 складу Конституційного Суду; Закон підвищує мінімальний вік для заняття посади судді з 25 до 30 років і при цьому докорінно змінює порядок обрання та звільнення суддів, вводить систему конкурсного відбору для призначення суддів тощо [1, ст. 532]. У рамках судової реформи Закон України «Про судоустрій і статус суддів» викладено у новій редакції від 02.06.2016 р. Так, ліквідовуються вищі спеціалізовані суди і оновлюється структура Верховного Суду України, зокрема створюються нові Вищі антикорупційний та патентний (3 питань інтелектуальної власності) суди [2, ст. 545].

Положення конституційних змін у сфері правосуддя охоплюють не лише питання судоустрою та судочинства, але й реформування суміжних правових ін- 


\section{Цивільне, підприсмницьке, господарське та трудове право}

ститутів - прокуратури, адвокатури, безоплатної правової допомоги та виконання судових рішень, які є невід'ємними складовими юстиції.

У Конституції та Законі України «Про прокуратуру» закріплюється, що прокуратура втрачає загальну функцію нагляду і займається тільки підтриманням публічного обвинувачення в суді, представництвом інтересів громадян/держави в суді, процесуальним керівництвом досудовим розслідуванням та наглядом за виконанням судових рішень у кримінальних справах [3, ст. 12].

\section{Стан дослідження проблеми}

Робота носить своєчасний та комплексний характер, оскільки розкриває правову можливість громадян, передбачену Конституцією України щодо реалізації права на правову допомогу і вибір захисника через призму останніх конституційних змін, які торкнулися майже всіх галузей права. 3 огляду на це, наука юриспруденції має дефіцит праць з цієї проблематики і висвітлює відповідні питання епізодично або в рамках розгляду інших проблем. Як правило, праці присвячені інституту безоплатної правової допомоги, реалізації права на правову допомогу у кримінальному судочинстві, окремим аспектам адвокатської діяльності тощо. Проте, слід відмітити роботи Шрамко Ю.Т., Личко В.С. та Джуської А.В., які протягом 2013-2018 років дослідили це питання на рівні дисертаційних досліджень, а саме: законодавче врегулювання конституційного права на правову допомогу в Україні; поняття та види правової допомоги в Україні; конституційне право людини на професійну правничу допомогу в Україні.

Метою i завданням дослідження e з'ясування реалізації конституційного права громадян України на правову допомогу та доступ до справедливого суду через призму конституційних змін у частині правосуддя; визначення ступеня монополії адвокатури в національному законодавстві України; порівняння національного та міжнародного законодавства щодо реалізації права громадян на правову допомогу та ступеня участі у ній інституту адвокатури.

\section{Виклад основного матеріалу дослідження}

Відповідно до конституційних змін в Україні представляти та захищати громадян у суді зможуть тільки адвокати. Ця норма почала діяти 31 січня 2020 р. Іншими словами, йдеться про так звану «монополію адвокатів у суді». Хоча для державних органів та органів місцевого самоврядування, корпоративних юристів та законних представників зроблено виняток. Проте ці зміни ведуть саме до монополії адвокатів, адже жоден інший юрист не зможе здійснювати судовий захист прав і свобод фізичних та юридичних осіб.

Нагадаємо, що перший крок у цьому напрямі було здійснено в рамках кримінального судочинства. За новим Кримінальним процесуальним кодексом України (2012 р.), тільки адвокат може бути захисником підозрюваного чи обвинуваченого, представником потерпілого, цивільного позивача чи відповідача. Тоді як раніше таку функцію міг здійснювати фахівець у галузі права. До того ж відповідно до ст. 19 Закону України «Про адвокатуру та адвокатську діяльність» (2012 р.) за адвокатами давно уже закріплене право представництва і захисту інтересів фізичних та юридичних осіб у судах під час здійснення конституційного, адміністративного, цивільного, господарського, кримінального судочинства та розгляду справ про адміністративні правопорушення.

Законом № 1401-VIII від 2 червня 2016 р. на найвищому рівні унормовано виключну роль адвокатури у наданні правової допомоги, а саме: ст. 59 Конституції України прийнята в новій редакції - термін «правова допомога» замінений «професійною правничою допомогою», скасована частина друга. «Кожен має право на професійну правничу допомогу. У випадках, передбачених законом, ця допомога надається безоплатно. Кожен є вільним у виборі захисника своїх прав». Відповідно до нововведеної ст. 1312 носіями про- 
фесійної правничої допомоги є винятково адвокати. Так, «для надання професійної правничої допомоги в Українідіє адвокатура. Тільки адвокат здійснюе представництво іншої особи в суді, а також захист від кримінального обвинувачення».

Це означає, що до прийняття відповідних змін до Конституції України, представляти та захищати інтереси громадян та юридичних осіб у адміністративних, цивільних, господарських справах та справах про адміністративні правопорушення мали право фізичні особи чи організації (громадські) за довіреністю. Із вступом у юридичну силу окремих положень Основного Закону громадяни чи будь-які організації та юридичні особи, за неможливості захищати себе у суді, будуть змушені звертатися за правовою допомогою до адвокатів.

Звісно, Конституційні норми є основоположними, вони не можуть врегулювати абсолютно всі відносини, які виникають, i саме тому на їх виконання та задля деталізації положень приймаються закони [4]. Але незрозумілою є потреба встановлення монополії адвокатури саме на конституційному рівні. Оскільки в Україні діяв і був прийнятий новий профільний Закон «Про адвокатуру та адвокатську діяльність», яким чітко визначені види адвокатської діяльності, в тому числі і право судового захисту у всіх судових справах та інстанціях. Такою ж є практика європейських держав щодо цього питання, де рівень процесуальних законів вважається достатнім для встановлення повної або часткової монополії адвокатури (Франція, Бельгія, Португалія, Німеччина, Нідерланди, Аитва).

У світі «монополія адвокатів» на представництво інтересів в судах існує досить давно, як правило, в країнах «сталих демократій» Свропи та світу. Саме виникнення адвокатури як професії історично було зумовлене необхідністю виокремлення певної частини юристів, кваліфікація яких вважалася достатньою для здійснення професійного захисту особи в суді. Якщо ж говорити про Україну, це - новація для вітчизняного права, як і для права країн пострадянського простору. Пікантності додає те, що «монополія» $є$ конституційною, чого немає в інших країнах, навіть найрозвиненіших [5].

Положення Основного Закону - норми прямої дії, які від дня набуття чинності зроблять неконституційними низку положень інших законів, що стосуються надання правової допомоги. Тому існують неабиякі ризики, запобігти яким слід на рівні вдосконалення спеціального законодавства у сфері правових послуг.

Незважаючи на те що зміни до Конституції прийняті і частина нововведень уже діє, дискусії та обговорення в частині правосуддя та запровадження монополії адвокатів тривають. Представники державних органів та адвокатська спільнота однозначно виступають за такі зміни і вбачають у них тільки плюси. Зокрема, Олексій Філатов, заступник глави Адміністрації Президента України, член Ради з питань судової реформи при Президентові України, член Конституційної комісії, зауважує: «Наша мета - це точно не реформа заради реформи. Правосуддя - це не тільки суд. А що стосується професії адвоката ми прагнутимемо до діяльності за єдиними високими стандартами. А отже, суть має зводитись до основних пунктів: забезпечення максимальної якості надання послуг правниками, високі етичні стандарти та забезпечення прав та гарантій адвокатів» [6]. «А підсилення прав адвоката - по суті підсилення прав клієнта. I не слід забувати, що разом з гарантіями, правами, новими видами адвокатської діяльності ми матимемо значно більше обов'язків та відповідальності», - окрема позиція адвокатів. На думку голови Ради Київської області Петра Бойка, «монополія адвокатів у суді - це не створення якоїсь привілейованої “касти”, а перш за все підвищення рівня судового захисту» [7].

Отже, виключне право на представництво у судах та доступ до професії має належати лише адвокатам, оскільки саме вони наділені професійними правами та обов'язками, володіють належною підготовкою (мають спеціальну та достатню кваліфікацію), які гарантують якісні пра- 


\section{Цивільне, підприсмницьке, господарське та трудове право}

вові послуги та високий рівень судового захисту, що стимулюються не тільки високими гонорарами, а й можливістю притягнення їх до дисциплінарної відповідальності. До того ж усунення з правової арени «неякісних гравців» полегшить суддям роботу, адже їм легше вести процес $з$ юридично обізнаною особою - такої позиції дотримуються прихильники монополізації правових послуг.

Абсолютно протилежних поглядів стосовно монополії адвокатури на рівні Основного Закону дотримуються окремі адвокати, корпоративні юристи, правозахисники різних організацій та наукова спільнота. На їхню думку, у внесених змінах $е$ істотні недоліки.

По-перше, у світі не існує жодних прецедентів встановлення на рівні Основного Закону держави монополії недержавної самоврядної організації на надання послуг суспільству. Україна може стати першою країною у світі, яка закріплює протекціонізм на конституційному рівні. На сьогодні українська адвокатура знаходиться на такому рівні розвитку, який не дає змоги гарантувати надання якісних правових послуг. Українська адвокатура ще не досягла рівня розвитку на кшталт"bar assosiation”, як у СШІА, та високого авторитету у суспільстві, як у Великій Британії, Франції, Німеччині чи Бельгії. Адвокатам ніхто не забороняє своєю працею доводити якість своєї роботи та брати участь у будь-яких судових процесах, тому всі пропозиції щодо наділення цього інституту монопольними повноваженнями на участь у судових процесах мають визначатись тим, чи слугуватиме це захисту прав людини.

По-друге, прийняті зміни до Основного Закону перетворюють на обов'язок громадянина те, що досі було для нього однією із можливостей (правом), і звужують коло цих можливостей, а значить, звужують обсяг права на отримання правової допомоги. Зміни є необгрунтованим обмеженням права людини на вибір захисника. Це неминуче призведе до подорожчання послуг адвокатів, які в умовах відсутності у клієнта іншої альтернативи отримають монопольне становище на ринку.

По-третє, монополія адвокатури може сприяти негативному впливу на стан самої адвокатури та призвести до стагнації розвитку правової системи. Адвокатура може легко стати інструментом впливу держави на юридичну спільноту, позбавляючи можливості адвокатів, які захищають правозахисників, журналістів, представників опозиції, права брати участь у судових процесах.

По-четверте, встановлення монополії адвокатури у сфері юридичної допомоги становить загрозу для доступу до правосуддя соціально вразливих та незахищених верств населення, на яких поширюється система безоплатної правової допомоги. Подорожчання послуг, у випадку відсутності необхідних коштів у бюджеті, призведе до зменшення в рази безоплатної правової допомоги.

По-п'яте, прийняті зміни до Конституції України в частині встановлення абсолютного (виключного) права адвокатури на представництво в суді знаходять своє логічне продовження у Законах України «Про адвокатуру та адвокатську діяльність», «Про судоустрій і статус суддів», Кримінальному процесуальному кодексі України, але ніяким чином не узгоджуються із положеннями цивільного, господарського, адміністративного процесуального законодавства, а також Кодексу про адміністративні правопорушення. Так, відповідно до окремих положень процесуальних кодексів України, окрім КПК України, право на надання правової допомоги у суді надається також представникам та фахівцям з права.

\section{Висновки}

На нашу думку, відповідні зміни до Основного Закону у сфері надання правової допомоги є поспішними, необгрунтованими і такими, що не відповідають основним принципам права, передусім верховенству права та окремим статтям Конституції України (ст. 22, 59, 64) - кожен має право на правову допомогу та вільний вибір захисника. Конституційні 
права і свободи гарантуються і не можуть бути скасовані, при прийнятті нових законів або внесенні змін до чинних законів не допускається звуження змісту та обсягу існуючих прав і свобод [8, ст. 2598]. Таким чином, зміна положень про вільний вибір захисника чи представника відносно закріплених прав і свобод людини і громадянина є обмеженням або скасуванням їх, а саме: рішень Конституційного Суду України № 13-рп/2000 від 16 листопада 2000 р. про право вільного вибору захисника та № 23-рп/2009 від 30 вересня 2009 р. про право кожного на правову допомогу [9, ст. 2045, ст. 32]; міжнародно-правових договорів, згода на обов'язковість яких надана Верховною Радою України, зокрема ч. 3 ст. 6 Конвенції про захист прав людини і основоположних свобод (1950р.) та ч. 3 ст. 14 Міжнародного пакту про громадянські і політичні права (1966р.), що наголошують на вільному доступі до правової допомоги та виборі на свій розсуд захисника [10], основних принципів, що стосуються ролі юристів (1990р.) і передбачають право кожної людини звернутися до будь-якого юриста за допомогою для захисту й обстоювання своїх прав [11]; практики Европейського суду з прав людини (24 листопада 2011 р. ЄСПЛ оприлюднив рішення у справі «Загородній проти України» [12, ст. 1330], яким встановив, що недопуск у кримінальному процесі як захисника підсудного «фахівця в галузі права», який не має адвокатського свідоцтва, є порушенням права на справедливий суд Конвенції про захист прав людини і основоположних свобод та несумісний із принципом верховенства права).

\section{Мітература}

1. Про внесеннязмін до Конституції України (щодоправосуддя): Закон Українивід 02 червня 2016 року. № 1401-VIII. ВідомостіВерховної Ради України. 2016. № 28. Ст. 532.

2. Про судоустрій і статус суддів: Закон України від 02 червня 2016 року № 1401-VIII. Відомості Верховної Ради України. 2016. № 31. Ст. 545.
3. Про прокуратуру України: Закон України від 14 жовтня 2014 року № 1697 VII. Відомості Верховної Ради України. 2015. № 2-3. Ст. 12.

4. Олександров Д. Монополія адвокатури: що на нас чекає? Юридична газета. 2016. 30 травня. URL: http://yur-gazeta. com/publications/practice/ inshe/monopoliya-advokaturi-shcho-na-nas-chekae.html

5. Шепель Т. Адвокатська монополія: закон як дишло. Новий час. 2016. 10 червня. URL: http:// nv.ua/ukr/opinion/ shepel/advokatska-monopolija-zakon-jakdishlo-145187.html

6. Монополія адвокатури: варто чи ні іiі запроваджувати. Українське право. URL:http://ukrainepravo.com/news/ ukraine/monopol-ya-advokaturi-varto-chi-nzaprovadzhuvati/

7. Адвокатська монополія підвищить рівень судового захисту. Закон і Бізнес. URL: http://zib.com.ua/ua/print/88732advokatska_monopoliya_pidvischit_riven_ sudovogo_zahistu.html

8. Конституція України від 28 червня 1996 року. Офіційний вісник України. 2010. № 72/1. Ст. 2598.

9. Рішення Конституційного Суду України у справі за конституційним зверненням громадянина Солдатова Геннадія Івановича щодо офіційного тлумачення положень статті 59 Конституції України, статті 44 Кримінально-процесуального кодексу України, статей 268, 271 Кодексу України про адміністративні правопорушення (справа про право вільного вибору захисника) від 16 листопада 2000 року. № 13-рп/2000. Офіційний вісник України. 2000. № 47. Ст. 2045; Рішення Конституційного Суду України у справі за конституційним зверненням громадянина Голованя Ігоря Володимировича щодо офіційного тлумачення положень статті 59 Конституції України (справа про право на правову допомогу) від 30 вересня 2009 року. № 23-рп/2009. Вісник Конституційного Суду України. 2009. № 6. С. 32.

10. Конвенція про захист прав людини і основоположних свобод Ради Европи від 04 листопада 1950 року. Ратифікована Законом № 475/97-ВР від 17 липня 
Цивільне, підприсмницьке, господарське та трудове право

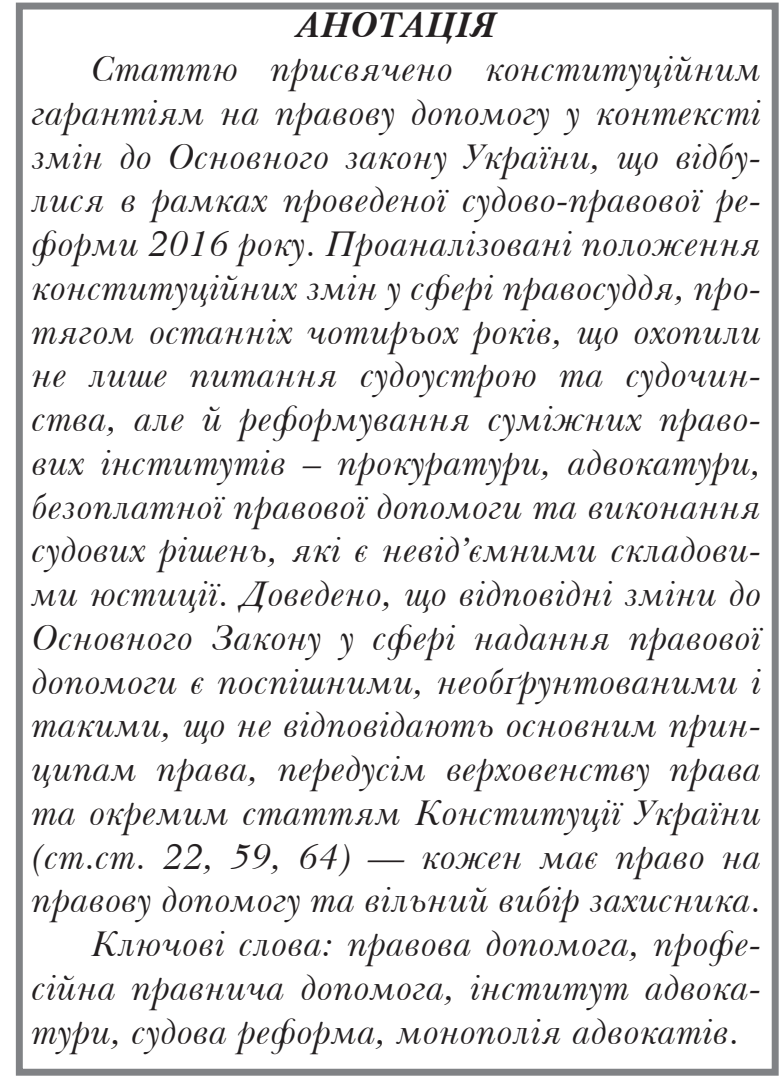

1997 року. Голос України. 10.01.2001. № 3; Міжнародний пакт про громадянські і політичні права ООН від 16 грудня 1966 року. Ратифікований Указом Президії ВР УРСР № 2148-VIII від 19 жовтня 1973 року. URL: http://zakon0.rada.gov.ua/ laws/show/995_043

11. Основні принципи, що стосуються ролі юристів, прийняті Конгресом ООН від 07 вересня 1990 року. URL: http:// zakon4.rada.gov.ua/laws/show/995_313

12. Рішення Європейського суду з прав людини у справі «Загородній проти України» від 24 листопада 2011 року. Офіційний вісник України. 2012. № 35. Ст. 1330.

\section{SUMMARY}

The article is devoted to the constitutional guarantees for legal aid in the context of amendments to the Basic Law of Ukraine, which took place in the framework of the judicial and legal reform of 2016. The provisions of the constitutional changes in the field of justice over the last four years have been analyzed, covering not only the judiciary and the judiciary, but also the reform of related legal institutions - the prosecutor's office, the bar, free legal aid and enforcement of judgments. It is proved that the relevant amendments to the Basic Law in the field of legal aid are hasty, unfounded and do not comply with the basic principles of law, especially the rule of law and certain articles of the Constitution of Ukraine (Articles 22, 59, 64) everyone has the right for legal assistance and free choice of defense counsel.

There is no precedent in the world for establishing at the level of the Basic Law of the state a monopoly of a non-governmental self-governing organization to provide services to society. The analysis and generalization of the international legislation regulating the activity of the bar gave the author the opportunity to draw the following conclusions: Ukraine may become the first country in the world to consolidate protectionism at the constitutional level; today the Ukrainian legal profession is at a level of development that does not guarantee the provision of quality legal services; the Ukrainian bar has not yet reached the level of development such as "bar association", as in the United States, and high authority in society, as in Great Britain, France, Germany or Belgium; No one forbids lawyers to prove the quality of their work and to take part in any legal proceedings, so any proposal to give this institution a monopoly on litigation should be determined by whether it serves to protect human rights.

Key words: legal aid, professional legal aid, institute of advocacy, judicial reform, monopoly of lawyers. 